Click www.researchjournal.co.in/online/subdetail.html to purchase.

Volume 5 | Issue 2 | September, 2014 | 224-230 @ e ISSN-2231-6434 |

International Research Journal of Agricultural Economics and Statistics

Visit Us - www.researchjournal.co.in DOI : 10.15740/HAS/RJAES/5.2/224-230

\title{
Research Paper Perspectives and prospects of milk production in Western Maharashtra
}

See end of the paper for authors' affiliations

Correspondence to :

\section{D.B. YADAV}

Department of Agricultural Economics, Mahatma Phule Krishi Vidyapeeth, Rahuri, AHMEDNAGAR (M.S.) INDIA Email:dbyadav@gmail. com

Paper History :

Received : 13.06 .2014

Revised : 14.07.2014;

Accepted: 28.07 .2014
ABSTRACT : The present study examines the status of livestock, infrastructure and milk production in Maharashtra with special reference to western Maharashtra on the broad indicators of dairy development activities like livestock population, animal husbandry, veterinary facilities, breeding and health cover programmes. The dairy development in western Maharashtra and Maharashtra state was studied with the help of linear and compound growth rates for the various selected parameters. The population of less productive bovine (indigenous cattle and male cattle) has declined whereas that of productive animals like crossbred cows has increased. The population of ovines (like sheep and goat) has increased at faster rate compared to bovines. The different indicators of livestock development programme viz., artificial insemination, number of cases treated, vaccinations, number of veterinary aid centres and development of infrastructure such as hospitals, polyclinics and mobile vans, etc. have made progress over the period of time. The total milk production showed the increasing trend in western Maharashtra and the state as a whole.

KEY WORDS : Milk production, Prospectives, Prospects, Livestock population

HOW TO CITE THIS PAPER : Kaware, S.S. and Yadav, D.B. (2014). Perspectives and prospects of milk production in Western Maharashtra. Internat. Res. J. Agric. Eco. \& Stat., 5 (2) : 224-230. 